\title{
Histopathology and Anticolon Cancer Effects of Turmeric Ethanolic Extracts in Wistar Rats
}

Simeon-Lancelot, Dumomangi Dorcas, $\mathrm{MSc}$ Okolie, Nnaemeka Jireh Cosmas, Prof

Department of Medical Laboratory Sciences, Faculty of Health Sciences, Imo State University, Owerri, Nigeria

Mac-Fiberesima, Gborieneomie, PhD

Department of Medical Microbiology/Parasitology, University of Port

Harcourt Teaching Hospital Rivers State, Nigeria

Felix M. Onyije, PhD

Department of Medical Laboratory Science, Faculty of Basic Medical Sciences College of Health Sciences Niger Delta University, Wilberforce Island Yenegoa, Bayelsa State, Nigeria

Doi:10.19044/esj.2021.v17n14p147

Submitted: 18 June 2019

Accepted: 18 December 2019

Published: 30 April 2021
Copyright 2021 Author(s)

Under Creative Commons BY-NC-ND

4.0 OPEN ACCESS

Cite As:

Dumomangi Dorcas S-L. Jireh Cosmas O.N., Gborieneomie M-F. \& Onyije F.M. (2021). Histopathology and Anticolon Cancer Effects of Turmeric Ethanolic Extracts in Wistar Rats. European Scientific Journal, ESJ, 17(14), 147.https://doi.org/10.19044/esj.2021.v17n14p147

\section{Abstract}

Colon cancer is cancer that begins in the large intestine. It usually begins as small, non cancerous clumps that form inside the colon. It typically affects older adults and can occur at any age. The aim of this study is to investigate the histopathological changes of the colon of rats experimentally induced with cadmium chloride as well as the anticancer effect of the ethanolic extract of Curcuma longa. Thirty six healthy albino rats of both sexes were classified into six groups with each group comprising of five rats as follows ; group I: normal control rats, group 2: Cadmium Chloride induced rats, group 3: Aduracil-5 fluorouracil treated rats, Group 4: dimethyl sulfuroxide treated rats, groups 5 and 6 rats were treated with $875 \mathrm{mg} / \mathrm{kg}$ and $437.5 \mathrm{mg} / \mathrm{kg}$ of Curcuma ethanolic extracts respectively after initial induction of cancer with cadmium chloride. Comparative observation of the cadmium induced colon showed histopathological damage as evidenced by empty goblet cells, 
lacerated and suppressed mucosa, destruction of the surface epithelium, features which were lacking in the control and Curcuma longa treated colon. Curcuma treated colon exhibited marked improvement of the histomorphology whilst cadmium treated colon clearly showed tumor cells, cancer cells or invasive inflammatory cells. Adruracil-5fluorouracil\{an established anti colon cancer drugs $\}$ treated colon showed mild improvement in the histomorphology of the colon while the dimethyl sulfuroxide treated colon revealed an insignificant impact. The ameliorative effect on rat colon occasioned by administration of Curcuma ethanolic extract suggests that the plant product may have therapeutic activity against colon inflammation in albino rats.

Keywords: Curcumin, Histopathology, Cadmium Chloride, Wistar Rats, Anti-colon Cancer, Carcinogen

\section{Introduction}

Colon cancer, a disease of the large intestine is now of great public health concern all over the world. (Chan et al., 1983) Dietary factors are considered to play a major role in cancer etiology. Cancer is a serious clinical problem that posses significant social and economic challenges to the healthcare system (DeVincenzi et al., 1991). Despite improved imaging and molecular diagnostic techniques, colon cancer continue to affect millions of people globally (Bardin et al., (2014). Colorectal cancer is the third most common and leading cause of cancer related mortality (Ableman, 1993) cadmium is a toxic, hazardous and carcinogenic non essential heavy metal found in the air, water, soil and food. It is known to produce toxic effects in humans as well as in rats. The agency for toxic substance and disease registry (ATSDR) in Atlanta Georgia has listed cadmium as number 7 in its top 20 last of hazardous substances. Brouck et al., (1975) interestingly, in contrast to the toxic activity of cadmium chloride. Inducing wistar rats with cadmium chloride initiated a drastic histopathological change in the architectural of the colon. Alteration of the mucosa epithelial glands were destroyed. So turmeric was used to treat this condition for a period of 14 to 56 days, It was reported that high dose of turmeric extract exhibited considerable protective efficacy in the rats than the low dose turmeric ethanolic extract treated rats. (Huang et al., 1987). Thus with these properties, this study intend to examine the histopathology changes in the colon associated with cadmium chloride necrosis, inflammation and ulceration. Hence, the aim ascertain the efficacy curcumin in rendering protection against cadmium chloride induced colonic toxicity at the cellular level. 


\section{Methods}

\section{Collection of samples}

Rhizomes of turmeric plants were bought from oil mill Market, in Port Harcourt, Rivers State. Properly cleaned of soil and dust by washing with tap water.

\section{Plant extraction}

After collection, the rhizomes were allowed at room temperature $\left(25^{\circ} \mathrm{C}\right.$ $-30^{\circ} \mathrm{C}$ ) to constant room weight over a period of seven 30days. The rhizomes were taken to market, and pulverized by an industrial blending mechanize. A fine golden yellow earthy' smelling powder was obtained Curcumin powder. It is a warm bitter and pepper like flavor earthy mustard like-aroma. The powder was dissolved in ethanol, allowed for $72 \mathrm{hrs}$ for properly maceration and subsequently evaporated in a desiccation and obtained a fine extract. After the extract was taken and filtered by using a 0.45 millipore filter paper. With a rotary evaporator at $40^{\circ} \mathrm{C}$ and 200rpm and subsequently, on a steam bath at $40^{\circ} \mathrm{C}$. The semi-solid extract obtained was bottles and labeled accordingly. The fine dark brown extracts were stored in desiccators at room temperature until when the need arises.

\section{Experimental design}

Thirty-six (36) animals were divided into 6 groups, 6 rats in each group.

Group 1 (normal) with six animals

Group 2 (negative control) had six animal

Group 3 positive control) had six animal

Group 4 (TEE - group low dose)

Group 5 (TEE - group High dose)

Group 6 (Dimethyl Sulphuroxide)

Through out the experiment, group 1 animal were not treated but were given free access to normal animal feed and water adlabium.

Group 2 animals were induced with Cadmium Chloride

Group 3 animals were induced with cadmium chloride latter were treated with standard Adrucil - 5- fluorouracil anticolon cancer drug.

Group 4 and 5 were treated with turmeric ethanolic extract $437.5 \mathrm{mg} / \mathrm{kg}$ low dose, while $875 \mathrm{mg} / \mathrm{kg}$ represent high dose respectively. While group 6 was treated with DMSO. On day 14, 28, 42, 56 from each group rats were humanely sacrificed using diethyl ether as anesthesia, colon harvested for assessment and examination.

\section{Challenging Apparently healthy Animal with Cadmium Chloride}

Thirty (30) animal (groups 2-6) were challenged with an induction dose of $20 \mathrm{mg} / \mathrm{kg}$ of cadmium chloride. After induction, we observed signs like 
weakness, anorexia, non-productive cough, watering stool, standing of the hairs or furs. Sluggishness, non-agility.the animals were prepared for treatment.

\section{Preparation of the extract concentration and anticancer drug}

The brown colour paste of turmeric extract were prepared by dissolving $5 \mathrm{mg}$ in $1 \mathrm{ml}$ of dimethyl sulfuroxide (DMSO) which was given to the rats by gavage. $0.02 \mathrm{ml}$ of Adrucil -5flourouracil $(500 \mathrm{mg} / 10 \mathrm{ml})$ was administered intraperitonaeally to rats respectively.

\section{Organ collection and assessment}

After the animals were anaesthetized with diethyl ether in a desiccators, the colon was removed aseptically and was weighed and was kept in $10 \%$ buffered formaline for histological analysis.

\section{Histopathology studies}

Formalin fixed colon were removed from fixative and various histological procedures were conducted on the colon noting the length and its colour.

Grossing; received a colon tissue with smooth external surface measuring 11 $x 1.0 \mathrm{~cm}$ with grayish to tan in colour. It was cut to a size of $2 \mathrm{~mm}$ to $4 \mathrm{~mm}$ thickness. This was done to allow the fixative to readily penetrate the tissue. Ascending grades of alcohol; the tissue was exposed to different concentrations of alcohol for processing by standard method described by Baker (1945). The various stages includes

Dehydrate; using ascending grade of alcohol concentration 2 hour in each Clearing; using two changes of xylene to remove alcohol.

Impregnation in two changes molten paraffinic wax. This step will take $2 \mathrm{hrs}$ in each solution

Embedding in mould to give it a solid and firm support.

Microtomy; cutting tissue blocks into sections. colon tissues are sectioned using the precision device called the microtomy.

Staining colon sections with hematoxyhn and Eosin $(\mathrm{H} \times \mathrm{xE})$ and finally mounting it with a DPX mountant, cover slip and view under a light microscope.

\section{Results}

The effects of cadmium chloride in wistar rats resulted in a decreased activity rate in the rats. The animals at certain point were losing the furs on them, they look emaciated and became small physically. Some of the animals 
died. Cadmium chloride was administered intrarectally to all the animals. A slight decrease in their feeding as well as in sleeping habit was observed. The rats in normal control group were given only food and water all through the treatment period. There was no death recorded. The histopathology report reveals that the colon mucosa epithelial remained normal. No sign of toxicity seen. The rats in Adrucil-5-flourouracil group were treated with $0.5 \mathrm{ml}$ of $40 \mathrm{mg} / \mathrm{kg}$ of $\mathrm{Cdcl}$ for cancer induction. Then after 28 days were treated with $0.2 \mathrm{ml}$ of $500 \mathrm{mg} / 10 \mathrm{ml}$ adrucil 5 -flourouracil from day 28 to day 56,2 rats were recorded dead, the histology reveals that there was mild mucosal disruption.

The rats in Cadmium control group were treated with only cadmium chloride from day 0 to 28 days and was observed for the rest of the experimental period. Three (3) rats were recorded dead, the histology reveals severe laceration of the colon mucosal. The rats in the low and high dose Curcumin extract group were treated with $0.25 \mathrm{ml}(437.5 \mathrm{mg} / \mathrm{kg})$ and $0.5 \mathrm{ml}$ $(875 \mathrm{mg} / \mathrm{kg}$ ) daily orally from day 28 to day 56 of the treatment period, no death was however recorded. Histology reveals no healing and eodenatous mucosa. The rats in the DMSO group were treated with $0.2 \mathrm{ml}$ of dimethyl surlfuroxide orally from day 28 to day 56 of the treatment period. DMSO was used to dissolve Curcumin extract. It was reported to have anti-cancer property hence we decided to make a group to ascertain that claim. Three (3) rats died in this group. Histology report reveals severe mucosal ulceration and inflammation.

The weight of the colon after administration of Cadmium Chloride $\left(\mathrm{CdCl}_{2}\right)$ as shown in table 4 revealed that there was no weight gain in the colon of the experimental rat in the Adrucil control, but at day 42 and 56 in the Cadmium group as a result of edematous and inflammatory action of Cadmium on the mucosa walls of the colon ensured weight gain.

During Cadmium Chloride induction, there was increased stool consistency scores, Cadmium decreased weekly weight gain this finding is consistent with previous reports by (Chiarenza et al., 1989).

Table 1: Grossing Report of Rat Colon in control, Cadmium, Adrucil and DMSO Groups

\begin{tabular}{|l|l|}
\hline Normal Control Group & $\begin{array}{l}\text { The proximal and distal portions of the colon was the target } \\
\text { for investigation. Normal colons shows smooth external } \\
\text { surface with no obvious abnormally or defect present. The } \\
\text { physical appearance is grayish white measuring } 6.0 \times 1.0 \mathrm{~cm} .\end{array}$ \\
\hline Cadmium Group & $\begin{array}{l}\text { Colon showed undulating surface measuring } 6.0 \times 2.5 \mathrm{~cm} \\
\text { showing a tan to dark colour }\end{array}$ \\
\hline $\begin{array}{l}\text { Adrucil } \\
\text { Group }\end{array}$ & $\begin{array}{l}\text { Colon showed smooth external surface measuring } 6.0 \times 2.0 \mathrm{~cm} \\
\text { showing grayish to tan colour appearance. }\end{array}$ \\
\hline $\begin{array}{l}\text { Dimethyl Sulfur } \\
\text { Oxide Group }\end{array}$ & $\begin{array}{l}\text { Colon tissue showed undulating and irregular shape } \\
\text { measuring } 6.0 \times 2.0 \mathrm{~cm}, \text { showing soft to firm constituency } \\
\text { appearing grayish white. }\end{array}$ \\
\hline
\end{tabular}




\section{Keywords:}

Normal: (Animals not expose to any form of treatment but were fed ad libitum) Adrucil group (Animals treated with anti-colon drug) Dimethyl SuIphuroxide group (Animal treated with Dimethyl Surfur Oxide)

Table 2: Grossing Report of Animal Colon Treated with Ethanolic Extract

\begin{tabular}{|c|c|}
\hline Day 7 (TEE,LD) & $\begin{array}{l}\text { Received colon showed smooth external surface and patchy area } \\
\text { of dilated areas measuring } 7.1 \times 1.5 \mathrm{~cm}\end{array}$ \\
\hline Day 7 (TEE,HD) & $\begin{array}{l}\text { Received colon showed Undulating external surface, firm and } \\
\text { distended areas with tan colour measuring } 6.7 \times 2.0 \mathrm{~cm}\end{array}$ \\
\hline Day 14 (TEE,LD) & $\begin{array}{l}\text { Received partly tan to grayish white colon with firm portions } \\
\text { having undulating surface length measuring } 7.0 \times 2.0 \mathrm{~cm}\end{array}$ \\
\hline Day 14 (TEE,HD) & $\begin{array}{l}\text { Received colon showed firm tumor measuring } 3 \times 1.5 \mathrm{~cm} \text { with soft } \\
\text { areas at distal regions of the colon measuring } 6.0 \times 4.0 \mathrm{~cm}\end{array}$ \\
\hline Day 28 (TEE,LD) & $\begin{array}{l}\text { Received colon showed soft grayish undulating external surface } \\
\text { measuring } 6.5 \times 1.5 \mathrm{~cm}\end{array}$ \\
\hline Day 28 (TEE,HD) & $\begin{array}{l}\text { Received colon showed undulating smooth external surface with } \\
\text { grayish white colour measuring } 6.5 \times 1.5 \mathrm{~cm}\end{array}$ \\
\hline Day 42 (TEE,LD) & $\begin{array}{l}\text { Received colon showed smooth external surface with partly } \\
\text { grayish colour measuring } 6.0 \times 1.0 \mathrm{~cm}\end{array}$ \\
\hline Day 42 (TEE,HD) & $\begin{array}{l}\text { Received colon showed smooth external surface partly grayish } \\
\text { colour measuring } 6.0 \times 1.0 \mathrm{~cm}\end{array}$ \\
\hline Day 56 (TEE,LD) & $\begin{array}{l}\text { Received colon showed smooth grayish colour and pasty tan } \\
\text { measuring } 6.0 \times 1.0 \mathrm{~cm}\end{array}$ \\
\hline Day 56 (TEE,HD) & $\begin{array}{l}\text { Received colon showed smooth grayish colour appearance } \\
\text { measuring } 6.5 \times 1.0 \mathrm{~cm}\end{array}$ \\
\hline
\end{tabular}

\section{Keywords:}

TEE, LD: (Rats treated with low dose turmeric ethanolic extract) TEE,HD: (Rats treated with high dose turmeric ethanolic extract)

Table 3: Colon Weight Gain after Cadmium Administration in the Control Groups

\begin{tabular}{|c|c|c|c|c|}
\hline \multirow{2}{*}{$\begin{array}{l}\text { Colon weight of rat in } \\
\text { various groups. }\end{array}$} & Days & 28 & 42 & 56 \\
\hline & \multicolumn{4}{|c|}{ Colon weight in grams $(\mathrm{g})$} \\
\hline Normal control & 0.01 & 0.01 & 0.01 & 0.01 \\
\hline $\begin{array}{l}\text { Adrucil -5-flourouracil } \\
\text { group }\end{array}$ & 0.01 & 0.01 & 0.01 & 0.01 \\
\hline Cadmium group & 0.02 & 0.02 & 0.03 & 0.03 \\
\hline
\end{tabular}


Table 4: Histopathological Scoring of Rat Colon after Cadmium Induction and ric

\begin{tabular}{|c|c|c|c|c|c|c|c|c|}
\hline Groups & $\begin{array}{l}\text { No } \\
\text { of } \\
\text { Rats }\end{array}$ & $\begin{array}{l}\mathrm{Cdcl}_{2} \\
40 \mathrm{mg} / \mathrm{kg} \\
(\text { Day } 0)\end{array}$ & $\begin{array}{l}\text { Histopathology } \\
\text { Report After } \\
\text { Induction }\end{array}$ & $\begin{array}{l}\text { Adrucil } \\
500 \mathrm{mg} / 10 \mathrm{mls} \\
\text { (Day 7) }\end{array}$ & $\begin{array}{l}\text { Curcumin } \\
\text { Extract } \\
437.5 / 875 \mathrm{mg} / \mathrm{kg} \\
\text { (Day 14) } \\
\end{array}$ & $\begin{array}{l}\text { DMSO } \\
0.2 \mathrm{mls} \\
\text { (Day } \\
28) \\
\end{array}$ & $\begin{array}{l}\text { No of } \\
\text { Death } \\
\text { (Day } \\
42 \text { ) } \\
\end{array}$ & $\begin{array}{l}\text { Histopathology } \\
\text { Report After } \\
\text { Treatment } \\
\text { (Day 56) }\end{array}$ \\
\hline $\begin{array}{l}\text { Normal } \\
\text { Control }\end{array}$ & 9 & - & $\begin{array}{l}\text { No Ulceration } \\
\text { or } \\
\text { inflammation. }\end{array}$ & - & - & - & Nil & Normal colon \\
\hline $\begin{array}{l}\text { Cadmium } \\
\text { Control } \\
\end{array}$ & 9 & 0.5 & Severe necrosis & - & - & - & 3 & Lacerated colon \\
\hline $\begin{array}{l}\text { Adrucil } \\
\text { Control } \\
\end{array}$ & 9 & 0.2 & $\begin{array}{l}\text { Severe } \\
\text { Inflammation }\end{array}$ & 0.2 & - & - & 2 & $\begin{array}{l}\text { Mild Mucosal } \\
\text { disruption }\end{array}$ \\
\hline $\begin{array}{l}\text { Curcumin Low } \\
\text { Dose }\end{array}$ & 9 & 0.5 & $\begin{array}{l}\text { Severe } \\
\text { laceration }\end{array}$ & - & 0.5 & - & Nil & $\begin{array}{l}\text { Complete } \\
\text { reversal/repair }\end{array}$ \\
\hline $\begin{array}{l}\text { Curcumin } \\
\text { High } \\
\text { Dose }\end{array}$ & 9 & 0.25 & $\begin{array}{l}\text { Severe } \\
\text { ulceration }\end{array}$ & - & 0.25 & - & Nil & $\begin{array}{l}\text { Mucosal } \\
\text { epithelia intact }\end{array}$ \\
\hline $\begin{array}{l}\text { DimethylSulfur } \\
\text { Oxide }\end{array}$ & 9 & 0.2 & $\begin{array}{l}\text { Severe } \\
\text { ulceration }\end{array}$ & - & - & 0.2 & 3 & $\begin{array}{l}\text { Moderate } \\
\text { ulceration. }\end{array}$ \\
\hline
\end{tabular}




\section{Histological Plates of the Colon \\ Photomicrograph of the Rat Colon}

The histopathology profile of the animal colon in Normal control group (Plate 1) reveals no aberrations, laceration, and the goblet cells present were filled, the mucosal epithelial remain intact. The Photomicrograph of colon showing histopathological profile of the animal colon treated with Andrucil -5 flourouracil standard in positive control (Plate 2, 7 and 12) showed localized area of glands within the mucosa, forming vague lymphoid folicules, enlarged goblets cells and lacerated muscular layer, reveals mucosal damage. The photomicrograph of rat colon in damage control treated with Cadmium Chloride $\left(\mathrm{Cdcl}_{2}\right)$ (plate 3, 8 and 13) showed blunt, suppressed and obviously delineating histopathological damage and total damage to the goblets cells were seen. Severe necrosis, inflammation and ulceration was seen and no smooth muscles. The photomicrograph of colon treated with (DMSO) (plate 4, 9 and 14) revealed severe inflammation as well as marked necrosis. The photomicrograph of colon treated with low dose turmeric ethanolic extract (plate 5,10 and 15) revealed mild ulceration of the mucosal epithelial cell while the high dose turmeric ethanolic extract (plate 6,11 and 16) displayed mild inflammation of the goblets cells with improved histomorphology suggesting that turmeric extracts exhibited anti-inflammatory responses to the histopathological damaged by cadmium.

Mucosa Epithelia

Lamina Propria

Epithelium

Intestinal Glands

Muscularis mucosa 


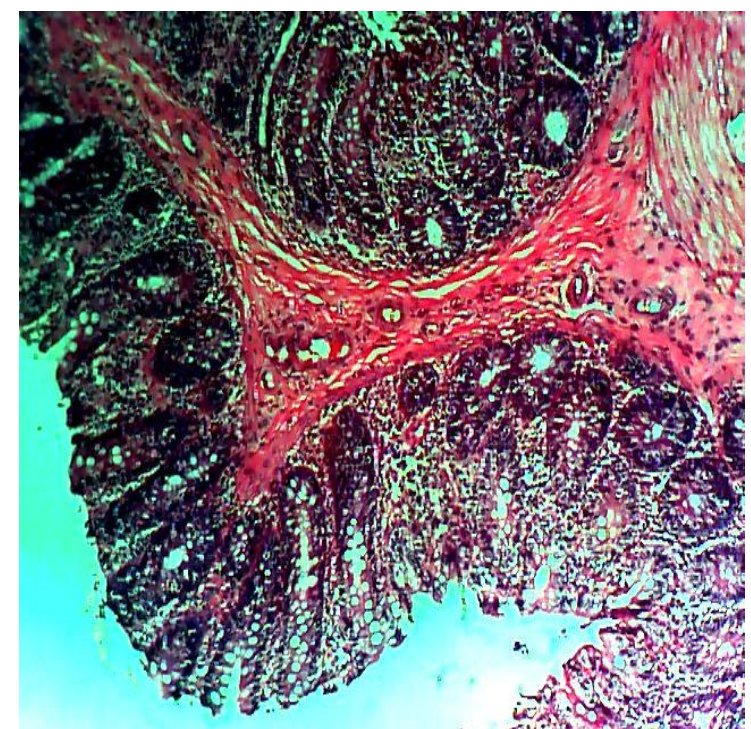

Plate 1: Photomicrograph of Normal colon

(Hematoxylin and eosin stain). Magnification X10. day 28

\section{Normal group;}

Photomicrograph of colon tissue of normal rats showing normal histoarchitecture with the epithelium, muscularis mucosa, intestinal glands, lamina propria and mucosa epithelia were seen intact no laceration or ulceration, no aberration in the colonic mucosa.

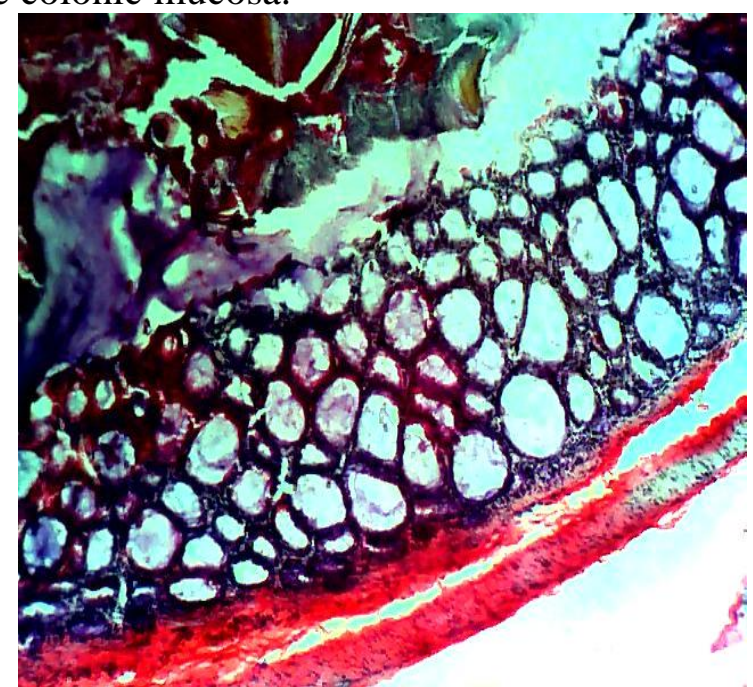

Plate 2: Photomicrograph of the colon of Adrucil-5-flourouracil treated Colon.

(Hematoxyline and eosine stain .MagnificationX10) day 28 
Photomicrograph of colon tissue showing localized area of glands within the mucosa, forming vague lymphoid folicules, enlarged goblets cells and lacerated muscular layer.

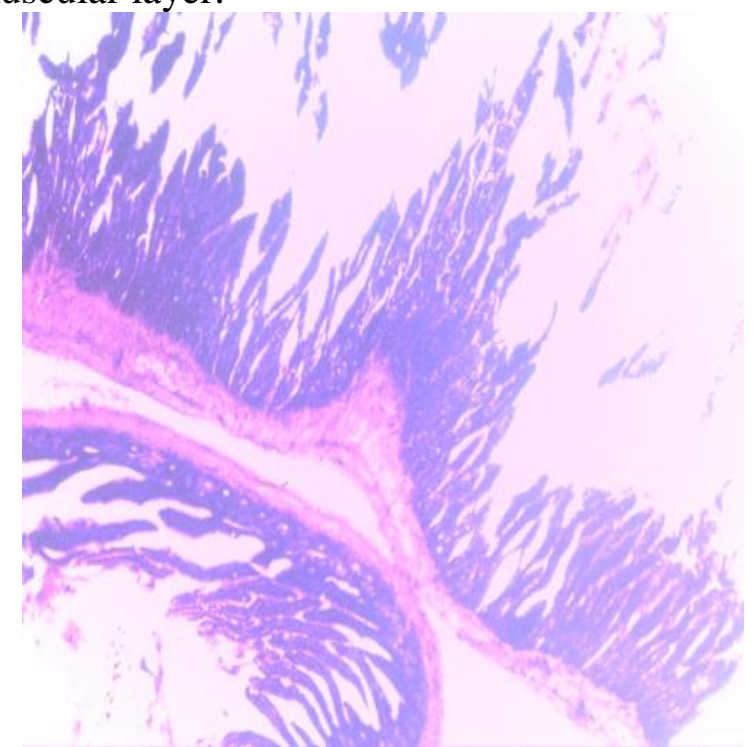

Plate 3: Photomicrograph of Cadmium treated colon (Hematoxyline and eosine stain; Magnification X10)day 28

Photomicrograph of colon tissue showing area of necrosis and sever inflammation, no smooth muscles and cancer cells within the muscular area.

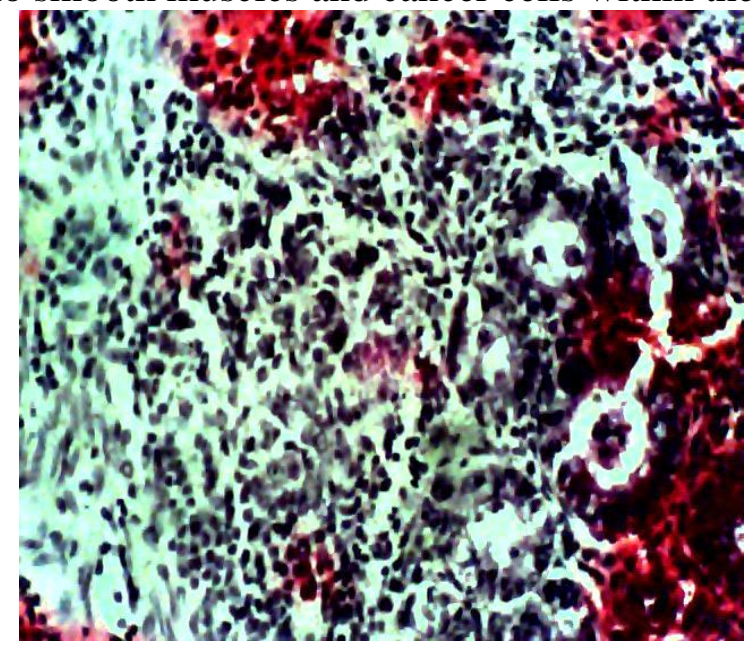

Plate 4: Photomicrograph Dimethylsulfuoxide treated column.

(Hematoxylin and eosin stain; Magnificationx10) day 28

Photomicrograph of colon tissue showing goblet cells lacerated and damaged, muscularies with glandular hyperplasia. 


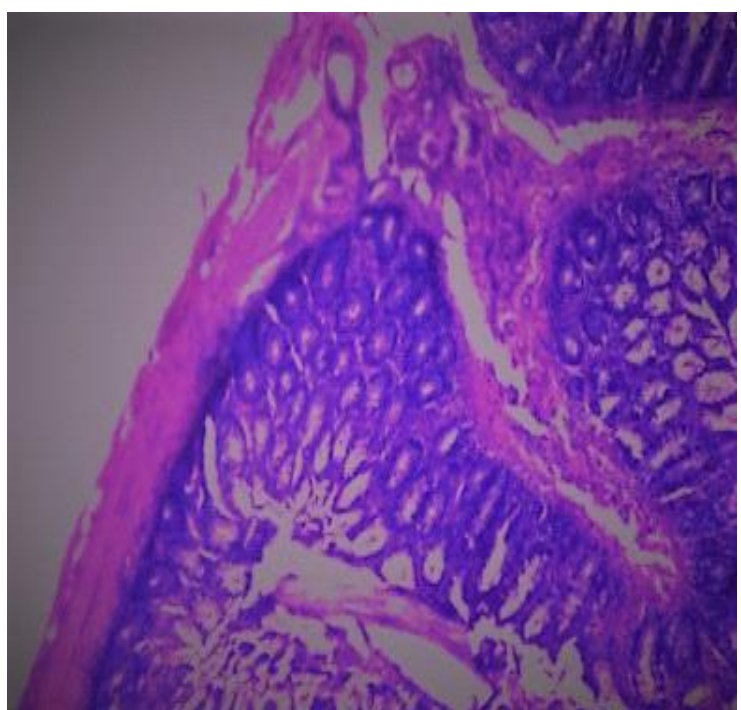

Plate 5: Photomicrograph Low dose Curcumin treated colon. (Hematoxylin and eosin stain; magnificationx 10) day 28

Photomicrograph of colon tissue showing goblet cells lacerated and damaged, muscularies with glandular hyperplasia.

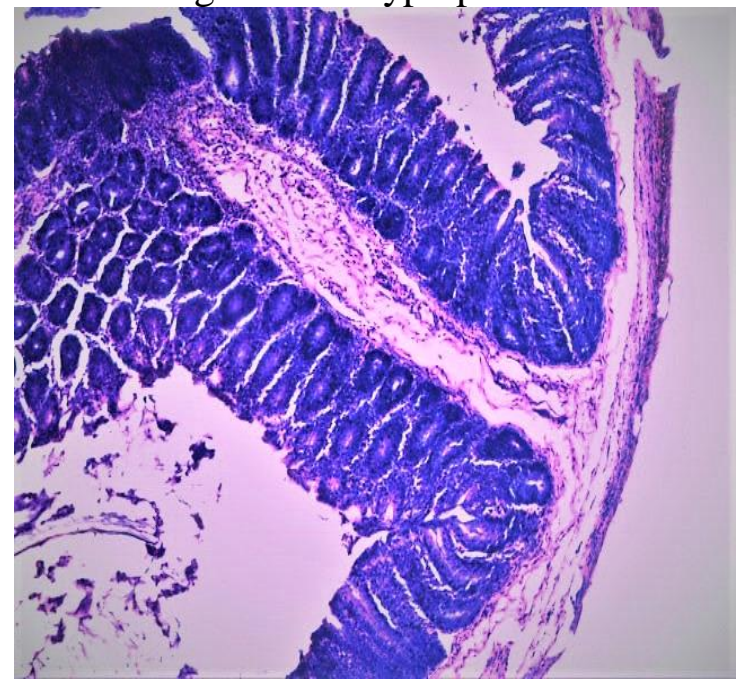

Plate 6: Photomicrograph of High dose Curcumin treated colon

(Heamatoxyline and eosine stain; magnificationx10)day 28

Photomicrograph of colon tissue showing areas of glands within the muscular area and goblet cells, few cancer cells with inflammatory cells. 


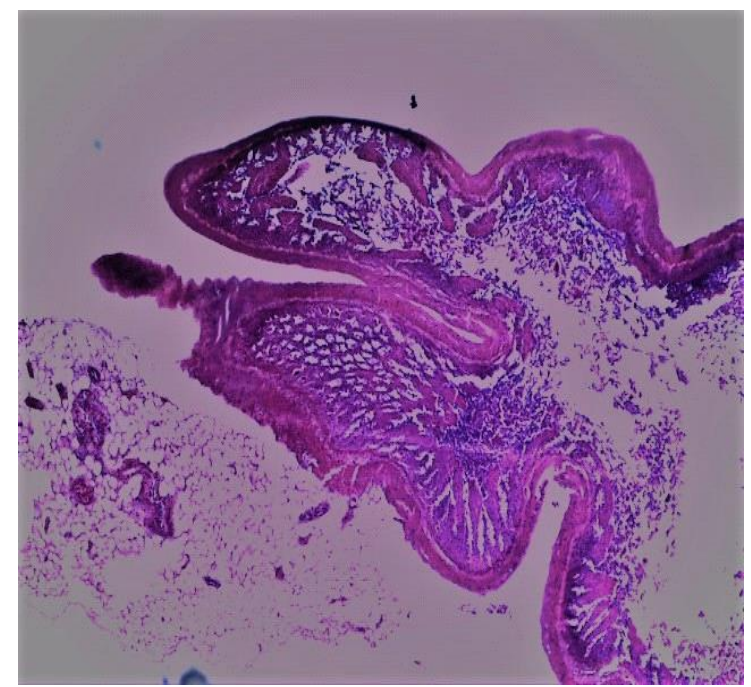

Plate 7: Photomicrograph of Adrucil-5-flourouracil treated colon.

(Hematoxylin and eosin stain; MagnificationX10) Day 42

Photomicrograph of colon tissue showing area of necrosis and inflammatory cells within the mucosa.

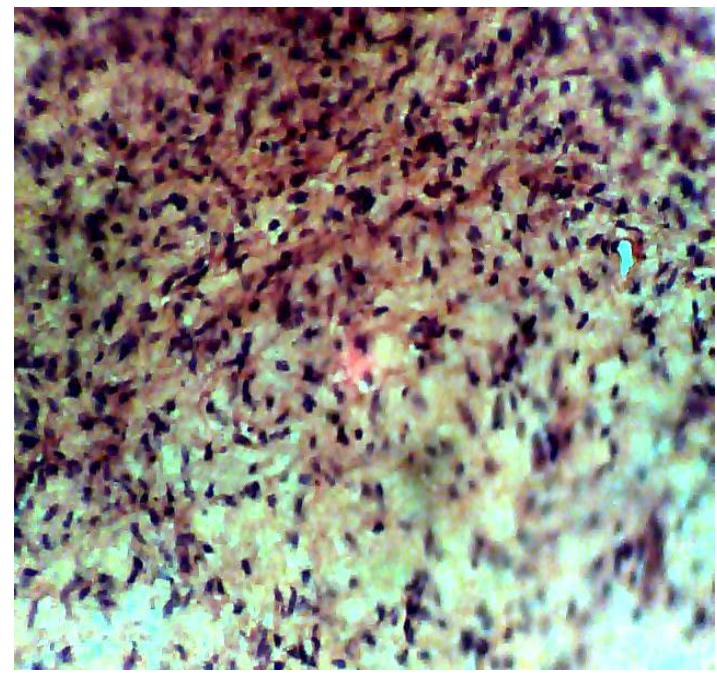

Plate 8: Photomicrograph of cadmium treated colon

(Hematoxylin and eosin stain; MagnificationX10) Day 42

Photomicrograph of colon tissue showing necrosis and sever inflammation, no smooth muscles and few cancer cells with inflammatory cells. 


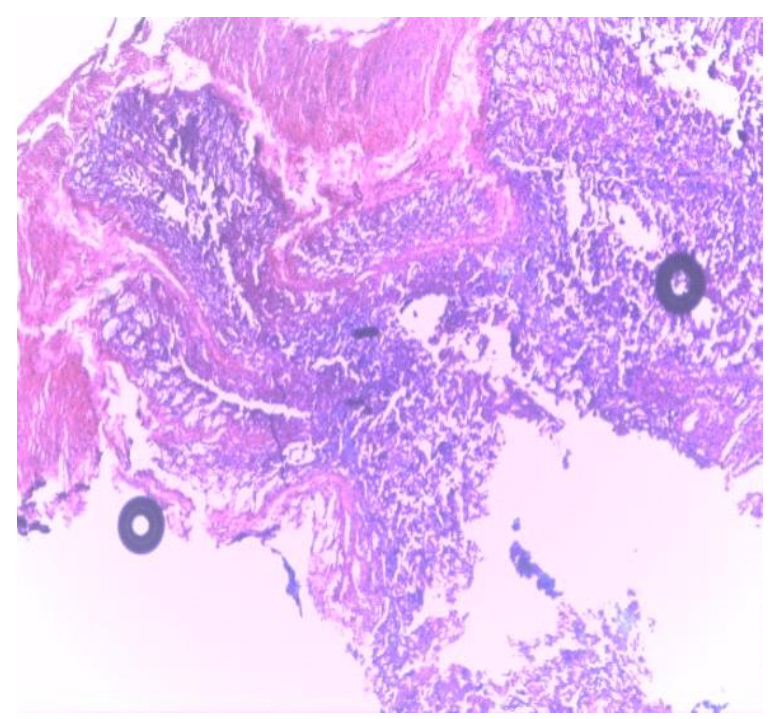

Fig 9: Photomicrograph of Dimethylsulphuroxide treated colon.

(Hematoxylin and eosin stain; MagnificationX10) Day 42

Photomicrograph of colon tissue showing goblet cells appear constricted with inflammatory cells.

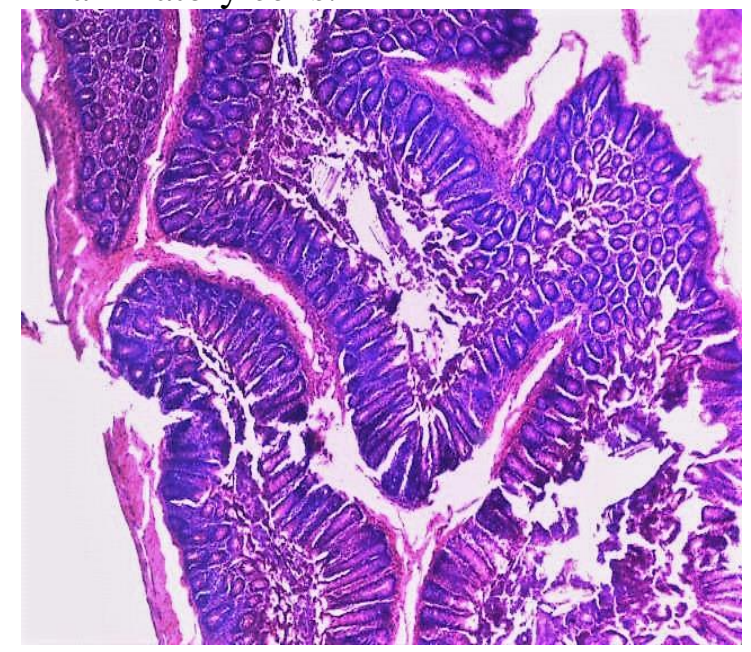

Plate 10: Photomicrograph of Low dose Curcumin treated colon.

(Hematoxylin and eosin stain;MagnificationX10) Day 42

Photomicrograph of colon tissue showing mild inflammation and blunt mucosa, goblet cells enlarged. Inflammation within the muscularis, goblets cells are reduced and area of necrosis within the adipose tissue. 


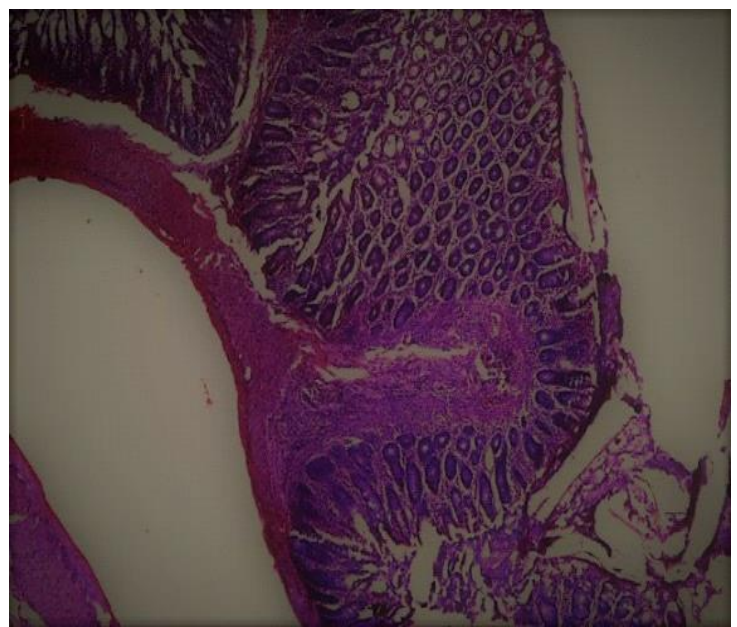

Plate 11: Photomicrograph of High dose Curcumin treated colon

Hematoxylin and eosin stain; MagnificationX10) Day 42

Photomicrograph of colon tissue showing moderate inflammation and no cancer cells.

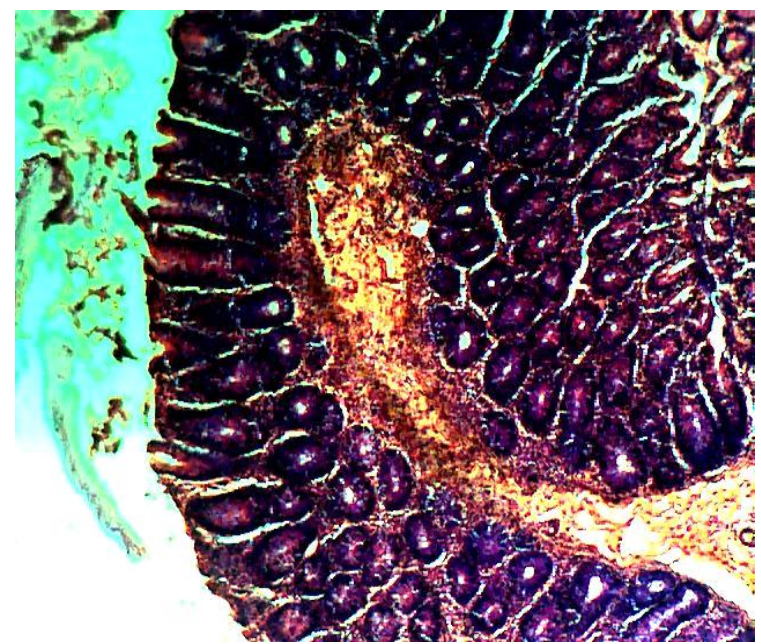

Plate 12: Photomicrograph of -5-Flourouracil treated colon (Hematoxylin and eosin stain; Magnification X10) Day 56

Photomicrograph of colon tissue showing mild inflammation and localized area in the muscularis filled with inflammatory cells. 


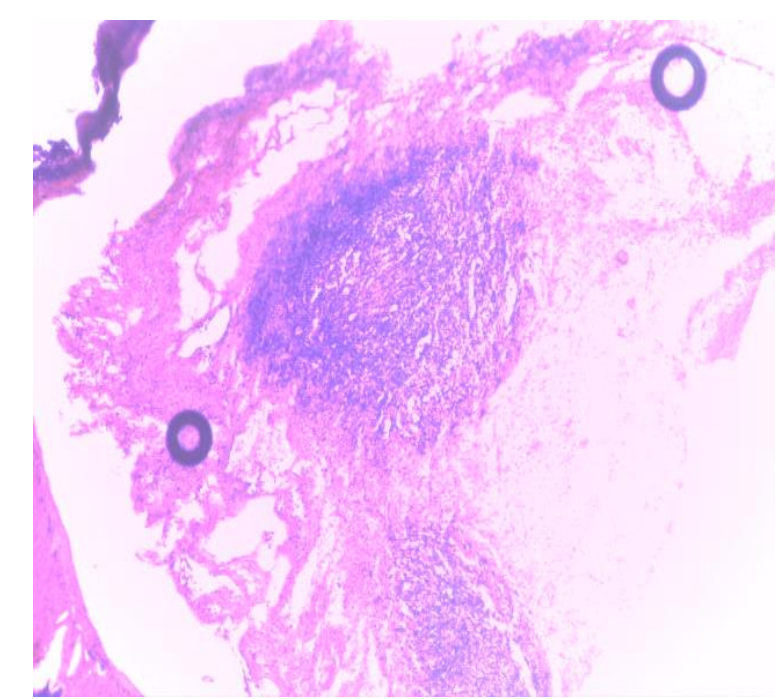

Plate 13: Photomicrograph of cadmium treated colon.

(Hematoxylin and eosin stain; Magnification X10) Day 56

Photomicrograph of colon tissue showing erosion of the mucosa epithelial, areas of necrosis and inflammatory cells and no cancer cells.

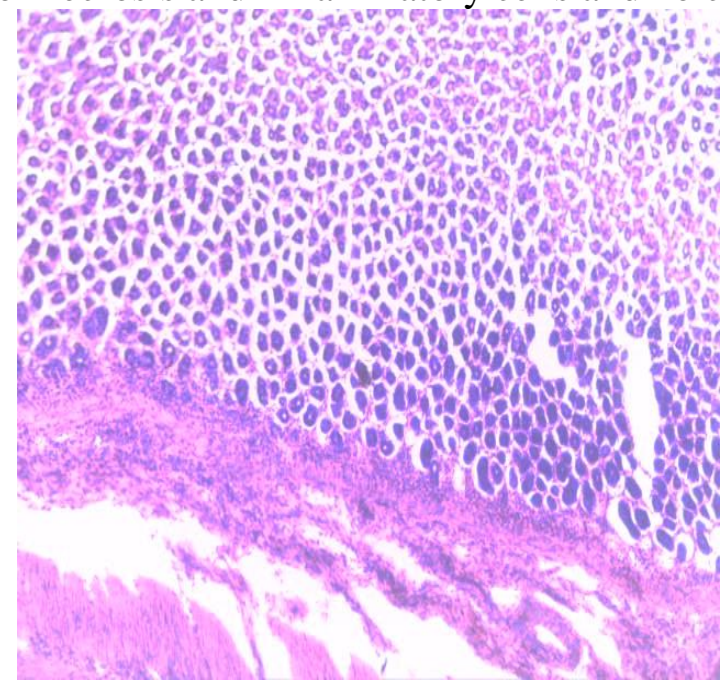

Plate 14: Photomicrograph of the colon of Dimethylsulfuroxide treated colon (Hematoxylin and eosin stain; MagnificationX10.) Day 56

Photomicrograph of colon tissue showing ulcerated mucosal layer, complete damage of the goblet cells and mucosa epithelial. 


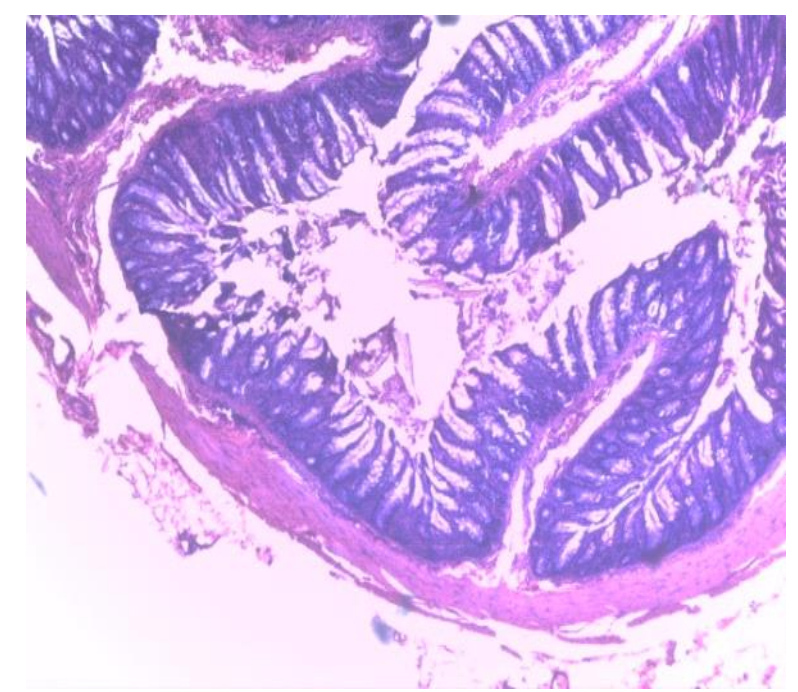

Plate 15: Photomicrograph of Low dose Curcumin treated colon (Hematoxylin and eosin stain; MagnificationX10) Day 56

Photomicrograph of colon tissue showing mild area of inflammation in the muscular area, areas close to normal and no cancer cells seen.

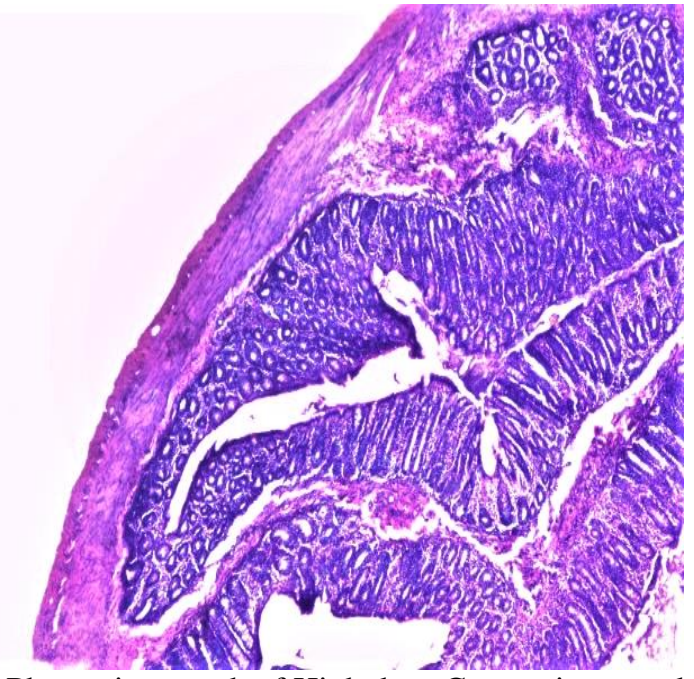

Plate 16: Photomicrograph of High dose Curcumin treated colon.

(Heamatoxylin and eosin stain; MagnificationX10.) Day 56

Photomicrograph of colon tissue showing mild eodema within the mucosa, reduced goblet cells and areas close to normal, muscularis with obvious vaocules and colon shows normal features of a colon.

\section{Discussion}

Histological evaluation showed that cadmium caused erosion of colonic epithelium, increased severity of colonic injury. The majority of 
cadmium exposure arise from ingestion of food substance due to uptake of cadmium by plant from fertilizer, sewage sludge, manure and atmospheric deposition (Ando et al., 1998), the two major ways humans can take up cadmium is by smoking and eating food especially in vegetarian. They feed mainly on fruit and vegetables, these food type are rich in cadmium and so can greatly increase concentration in the human body (Friberg et al., 1985 Valiter et al., 1996). In human cadmium has a long half life which is declared to be of about 10 -30 years in kidney and $4.7-9.7$ years in liver (Cheng and Wang 1990). Interestingly, about an average of 5\% of the total orally ingested cadmium is absorbed in the intestine, but individual values ranges from less than $1 \%$ to more than $2 \%$.

This reflects the fact that humans do not have effective pathway for cadmium elimination, hence shows the phenomenon of bioaccumulation. Once cadmium is absorbed into the human system, it remains resident for many years. Where cadmium toxicity is concerned, colon is of prime importance. About $90-95 \%$ of cadmium that is excreted passes through the colon, hence colonic cells are exposed to cadmium in fecal matter as well to cadmium present in the circulation. In this present study, we assessed the toxic effects of cadmium chloride as well as to monitor the protective effects of Curcumin in colon of wistar rat on the basis of histopathological observations. The integrity of colon depends upon the balance between the hostle factors, one of them being cadmium which damages the mucosa, goblet cells etc and the protective factors such as certain internal secretions like mucin and certain external agents like Curcumin which render protection against cadmium toxicity.

The data obtained and photomicrograph view results are similar to the results of various studies where cadmium has been reported to cause variation on histo -architecture of colon. These reports revealed that intra rectal exposure as well as oral exposure to cadmium caused severe necrosis, hemorrhage and ulcers in the colonic epithelium as well induced decreased body weight and muscle atrophy (Farnsworth, 1992). (Adamsson, Piscator, and Nogawa, 1979). These various reports gave validity to our work where similar cadmium induced aberrations were observed. Curcumin in this study demonstrated a protective property or agent where it clearly initiated decrease congestion and inflammation in stagnant mucus membrane and no negative side effects have been associated with Curcumin supplementation (Mesa, et al., 2003). Curcumin also reduced ulcerative colitis (Deodhar et al., 1980) and (Ammon and Wahl, 1991). Curcuim has been shown to protectively coat the intestinal mucus membrane and reduce acid secretion. However, information available clearly delineates the protective effects of curcuimin against cadmium chloride induced colonic toxicity. Photomicrograph of colonic tissue 
of rats induced with cadmium and then treated with turmeric ethanolic extract high doses for 28, 42, 56 days have confirmed this claim.

\section{Conclusion}

Turmeric ethanolic extract (TEE) reversed the adverse pathological changes in the colon induced with cadmium chloride at $875 \mathrm{mg} / \mathrm{kg}$ and $437.5 \mathrm{mg}$. With the $875 \mathrm{mg} / \mathrm{kg}$ dose being more effective at reversing colonic changes when compared with Adrucil -5- fluorouracil anticancer drug. This findings suggest that curcuma longa in turmeric has anti inflammatory potential as well as anti necrotic tendency. The treatment with high does tends to be more effective than the low dose. The rat colon treated with DMSO shows little or no significant effect in the colonic morphology. It is obvious that Curcumin exhibited total protective effect on the mucosal epithelium of induced colon.

\section{References:}

1. Ableman, M. (1993). From the good earth: a celebration of growing food around the world.Harry N. Abrams. New York, NY. Pp.168.

2. Adamsson, E., Piscator, M. and Nogawa, K. (1979). Pulmonary and gastrointestinal exposure to cadmium oxide dust in a battery factory. Environmental and Health Perspective, 28:219-222.

3. Agency for Toxic Substances and Disease Registry (ATSDR) (1999). Case studies in environmental medicine: Cadmium toxicity. Atlanta, GA: Agency for Toxic Substances and Disease Registry; 1990b.

4. Aggarwal, B.B., Ichikawa, H. and Garodia, P. (2006). From traditional Ayurvedic medicine to modern medicine: Identification of therapeutic targets for suppression of inflammation and cancer. Expert Opinion Therapy on Targets, 10:87-118.

5. Akahori, F., Masaoka, T. and Arai, S. (1994). A nine-year chronic toxicity study of cadmium in monkeys. II. Effects of dietary cadmium on circulatory function plasma cholesterol and triglyceride. Vetenary and Human Toxicology, 36(4):290-294.

6. Åkesson, A., Julin, B. and Wolk, A. (2008). Long-term dietary cadmium intake and postmenopausal endometrial cancer incidence: A population-based prospective cohort study. Cancer Research, 68(15):6435-6441.

7. Alessio, L., Apostoli, P., and Forni, A. (1993). Biological monitoring of cadmium exposure: An Italian experience. Journal of Work and Environmental Health, 19:27-33. 
8. Alloway, B.J., Jackson A.P. and Morgan, H. (1990). The accumulation of cadmium by vegetables grown on soils contaminated from a variety of sources. Science Total Environment, 91:223-236.

9. Ammon, H.P. and Wahl, M.A. (1991). Pharmacology of Curcuma longa. Planta Medical 57:1-7.

10. Andersen, O, Nielsen, J.B. and Svendsen, P. (1988). Oral cadmium chloride intoxication in mice: Effects of dose on tissue damage, intestinal absorption and relative organ distribution. Toxicology, 48:225-236.

11. Ando M, Hiratsuka N, Nakagawa J, et al. (1998). Cadmium accumulation in rats treated orally with cadmium chloride for 8 months. Journal Toxicology of Science, 23(3):243-248.

12. Asai, A., Nakagawa, K. and Miyazawa, T. (1999). Antioxidative effects of turmeric, rosemary and capsicum extracts on membrane phospholipid peroxidation and liver lipid metabolism in mice. Bioscience Biotechnology and Biochemistry, 63:2118-2122.

13. Azuine, M.A. and Bhide, S.V. (1992a). Protective single/combined treatment with betel leaf and turmeric against methyl (acetoxymethyl) nitrosamine-induced hamster oral carcinogenesis. International Journal on Cancer, 51:412-415.

14. Bardin, C., Veal, G., Paci, A., Chatelut, E., Astier, A., Leveque, D., Widmer, N. and Beijnen, J. (2014). Therapeutic drug monitoring in cancer--are we missing a trick? European Journal Cancer, 50: 20052009.

15. Boonjaraspinyo, S., Boonmars, T. and Aromdee, C. (2009). Turmeric reduces inflammatory cells in hamster opisthorchiasis. Parasitology Research, 105:1459-1463.

16. Brouck, B. (1975). Plants consumed by man. Academic Press. New York, NY. pp.460..

17. Chan, H.T., Jr. (1983). Handbook of tropical foods. Dekker. New York, NY. 639 pp. Roberts, J. 2001. The origin of fruit and vegetables. Universe Publ. New York, NY. 228 pp. Szczawinski, A. F. \& G. A. Hardy. (1962). Guide to common edible plants of British Columbia. British Columbia Prov. Mus. Handbook No. 20. Victoria. 90 pp.

18. Tilford, G. L. 1997. Edible and medicinal plants of the West. Mountain Press Publication Missoula, Medicinal Treatment, 239 pp.

19. Chiarenza A, Elverdin JC, Espinal E, et al. (1989). Effects of cadmium on the function and structure of the rat salivary glands. Architecture of Oral Biology, 34:999-1002.

20. Deodhar, S.D., Sethi, R. and Srimal, R.C. (1980). Preliminary study on antirheumatic activity of curcumin (diferuloyl methane). Indian Journal of Medical and Research, 71: 632-634. 
21. DeVincenzi, M. and M. R. Dessi. (1991). Botanical flavouring substances used in foods: proposal of classification. Fitotherapia, 62(1): 39-63.

22. FAO. (1989). Utilization of tropical foods trees. Food and nutrition papers no. 47/3. Food and Agriculture Organization of the United Nations. Rome. pp.52.

23. Farnsworth, N.R. and Bunyapraphatsara, N. (1992). Thai Medicinal Plants (Recommended for Primary Health Care System). $1^{\text {st }}$ edition. Bangkok: Prachachon Press, pp. 130-142.

24. Fern, K. (1997). Plants for a future: edible and useful plants for a healthier world. Permanent Publication Clanfield, England. pp. 300.

25. Friberg, L., Nordberg, G.F. and Vouk, V.B. (1986). Handbook of the toxicology of metals. Amsterdam, Elsevier, 2: 130-184.

26. Habiboallah, G., Nasroallah, S. and Mahdi, Z. (2008).. Histological evaluation of Curcuma longa-ghee formulation and hyaluronic acid on gingival healing in dog. Journal of Ethnopharmacology, 120:335-341

27. Huang, G.L., Zhang, X.H. and Guo, G.L. (2009). Clinical significance of miR-21 expression in breast cancer: SYBR-Green I-based real-time RT-PCR study of invasive ductal carcinoma. Oncology Report, 21(3):673-679.

28. Ikeda, M., Zhang, Z.W., Moon, C.S., Shimbo, S. and Watanabe, T. (2000). Possible effect of environmental cadmium exposure on kidney function in the Japanese general population. International Archives of Occupational and Environmental Health, 73, 15-25.

29. Kositchaiwat C, Kositchaiwat S, Havanondha J. (1993). Curcuma longa Linn. in the treatment of gastric ulcer comparison to liquid antacid: A controlled clinical trial. Journal and Medical Association of Thailand,76:601-605.

30. Mesa, M.D, Aguilera, C.M. and Ramìrez-Tortosa, C.L. (2003). Oral administration of a turmeric extract inhibits erythrocyte and liver microsome membrane oxidation in rabbits fed with an atherogenic dietary. Nutrition, 19:800-804. 